\title{
Societal trends influencing mobility and logistics in Europe: a comprehensive analysis
}

\author{
Eleni Chalkia, Maria Teresa de la Cruz, Imre Keseru, Alain L’Hostis, Beate \\ Müller
}

Center for Research and Technology Hellas (CERTH), Greece, hchalkia@certh.gr, Zaragoza Logistics Center, Spain, mdelacruz@zlc.edu.es, Vrije Universiteit Brussel, Mobility, Logistics and Automotive Technology Research Centre (MOBI), Department Business Technology and Operations (BUTO), Pleinlaan 2, BE-1050 Brussel, Belgium, Imre.Keseru@vub.be, Université Paris-Est, LVMT (UMR_T 9403), Ecole des Ponts ParisTech, IFSTTAR, UPEMLV, F-77455 Marne la Vallée, France, alain.lhostis@ifsttar.fr, VDI/VDE Innovation und Technik GmbH, Germany, Beate.Mueller@vdivde-it.de

\begin{abstract}
The objective of this paper is to establish a comprehensive view of societal trends that have an impact on mobility and logistics in the future. We have reviewed scientific literature, the output of European research projects and reports from consultancies. The result of this investigation provides a broad and comprehensive set of factors that influence, and will influence in the future, mobility and logistics. The set is composed of 29 trends organised under 9 larger categories covering economic issues, societal issues, urbanisation, the environment, the digital society, new business models, safety, security and the legislative framework.

This work has been strongly inspired by the ideas of the liquid modernity developed by Bauman. This broad and complete view on societal trends has proved to be very supportive of the present analysis. It allows describing linkages between social and economic trends, and between society and technology, especially information and communication technology. Building the analysis on liquid modernity provides coherence and exhaustiveness in covering the topic. The added value of this contribution is its systematic approach and that evidence is provided for each identified trend.
\end{abstract}

\section{Introduction}

Understanding current and future mobility and logistics is a key element in order to shape transport policies and orientate future research. Therefore, establishing a comprehensive view of societal trends that have an impact on 
mobility and logistics, represents a significant step. In the context of the European research project Mobility4EU ${ }^{1}$, such an analysis was carried out (L'Hostis et al. 2016). The aim here is to present societal factors, in the broad sense, that influence mobility and logistics. Studying mobility of people and logistics together remains a challenging task. The "last mile" of logistics is very often a matter of individual mobility, which shows how interrelated the two topics can be. Mobility of persons is the most prominent topic in the study of societal trends, but logistics issues can nevertheless be found in several places in our contribution.

There is a broad consensus within scientific literature and in policies that mobility is of crucial importance for society. According to a study by the International Transport Forum in 2011 (Wilson 2011; 'ITF Transport Outlook 2017’2017), by 2050 passenger mobility will increase by a staggering 200-300 \% and freight activity by as much as $150-250 \%$.

Mobility is increasingly becoming so important that several authors proposed to replace the study of society by the study of mobility (Urry 2007). We chose not to separate society from mobility and transport, but rather to take an integrated approach.

A societal trend is described as an emerging pattern, movement, and evolution in society that leads to change, and potentially has implications for mobility and transport (e.g. ageing, social networks). Societal trends impact transport infrastructure and demand, thus they can be considered key elements for transport related change.

The analysis had to find a compromise between the need to identify and hence separate, and the need to highlight interactions between individual trends and groups of trends. In this perspective trends have been organised in groups of individual trends.

In this work, it has proven difficult to dissociate clearly societal trends from political trends. For example, it is difficult to identify if environmental issues have been led by changes within patterns of behaviour in citizesns or if it has been led by legislation. Likewise, it is difficult to dissociate societal trends from technological trends as expressed in the concept of digital society. Consequently, our analysis of societal trends that impact transport uses five domains of investigation: this analysis covers societal, political, technological, environmental, legal and economic trends.

Another difficulty of the present approach has been to produce a coherent set of trends, shaped around a general view of present and future social behaviour. In order to avoid bias, we chose not to rely only on the sociologists of mobility such as Kaufmann (Kaufmann 2002), Urry (Urry 2007) or Kellerman (Kellerman 2012), who tend to consider mobility (and immobility) as central societal values. Instead, we refer to a more general view on society, as contained in the idea of

1 The Mobility4EU project aims at producing a roadmap for mobility and logistics in 2030 starting from societal needs. The overall objective consists in linking present and future societal trends and needs to existing and emerging transport and mobility solutions. http://www.mobility4eu.eu 
liquid modernity introduced by the sociologist Z. Bauman (Bauman 2000). This proposal formulates many ideas described in the post-modern concept. This new phase of modernity can be seen as being characterised by five trends:

- a continuing movement of individualism;

- the development of fluidity, which can be seen positively with the ideas of change and innovation, but which also has a darker side with respect to the ideas of rupture and precariousness;

- the principle of an acceleration of the pace of existence, especially as it is felt through the experience of individuals;

- the emergence of social networks that gain more significance, as compared to the more stable and strong (Granovetter 1983) social ties of the family, or of the workplace;

- the introduction of the technologies of information and communication in almost all aspects of social life.

One of the merits of this approach is to establish links between domains. Liquid modernity links social dynamics with technology, with social and economic dynamics. In addition, if Bauman (Bauman 2000) intends to describe society and not mobility itself, building an analysis of mobility out of these elements is very straightforward. Liquid modernity provides a strong support to the list of trends exposed here especially through the linkages it creates between societal trends and between societal and technology trends.

Liquid modernity ideas provide direct insights for understanding persons' mobility, and also gives indications of how freight transport is and should be organised in the future. Needs are more individualised, personalised and hence logistic flow tends to be individual based. Fluidity and the feeling of acceleration converts into the need for immediacy as is reflected in the development of socalled "instant delivery" (Dablanc et al. 2017). These aspects are devised in the relevant trends.

The emergence of a consensus among social scientists can be observed (Clegg and Baumeler 2010) on the idea of a shift of society towards liquid modernity introduced by (Bauman 2000). In consequence, this view provides a sound basis for the analysis of societal trends having an impact on mobility and logistics.

As compared to other similar scientific exercises, this approach is broader and emphasises new trends. Several researchers have focused on trends in favour of sustainable transport (Rudinger, Donaghy, and Poppelreuter 2004; Boschmann and Kwan 2008), while others have studied trends from travel surveys in a single country (Frändberg and Vilhelmson 2011). As compared to other similar exercises in European research, our approach is rooted in the study of societal trends as opposed to a more classic transport demand analysis, found in for example TransForum (Anderton et al. 2015), TRANSvisions (Petersen et al. 2009), FUTRE (Bernardino, Vieira, and Garcia 2013), RACE2050 (Sena e Silva et al. 2013), EUTransportGHG (Sessa and Enei 2009), ORIGAMI (Lemmerer and Pfaffenbichler 2012) and VOYAGER (Brög, Barta, and Erl 2005). These approaches tend to separate trends along classic transport modes and transport markets, without extending into the study of societal trends. As opposed to these 
approaches, firstly we analysed societal dynamics in a broad sense, and secondly identified trends that have an interaction with mobility and logistics. In this work, societal trends are starting points instead of more traditionally starting with the identification of transport solutions or markets. This approach complements previous research. In addition, as opposed to more thematic approaches to studying societal trends, for instance CITYLAB on freight (Dablanc et al. 2016) or TransForum on several targeted transport sectors (Anderton et al. 2015), our analysis intends to cover all transport modes, all geographical scales and freight as well as passenger transport.

\section{Method}

The objective of this chapter is to establish a comprehensive view of societal trends that impact mobility and logistics. In this aim, a literature review has been conducted, encompassing published scientific sources, research reports and statistics sources.

In order to set up a comprehensive view, a list of trends has been created. A set of rules has been defined for the identification of these trends in relation to mobility and logistics. Firstly, a trend is coherent, not equivocal. A trend can carry a paradox, like the trend about the acceleration of liquid modernity, and a trend can also move in a single direction.

Secondly, a trend is not redundant. Bearing in mind the complex nature of societal issues, the task of building a set with little overlap has proved challenging.

Thirdly, the set of trends should not omit factors or tendencies in society in the broad sense that may exert an influence on mobility and logistics.

And finally, a trend must be described and supported by evidence found in the literature. Statistics, surveys, and figures are provided for each trend. These analytical elements determine the direction of the influence exerted on mobility and logistics. In cases where an idea was formulated without evidence, it was not considered as a trend.

\section{Societal, political, technological, environmental, legal and economic trends interacting with mobility and logistics}

We are developing an analysis of this system of trends in the present with a temporal horizon of 2030. Consequently, the description of trends aims at capturing the present situation and the dynamics of these trends in the future. 
The result of this process is the following list. This list can be seen as the shortest possible set of trends that allows describing present and emerging societal factors, in a broad sense, that have an impact on mobility, both for freight and passengers' mobility.

The list is composed of 29 trends organised under 9 larger categories. These larger categories cover economic issues, societal issues, urbanisation, the environment, digital society, new business models, safety, security and finally, the legislative framework. Table 1 lists the categories and the trends, and indicates the type of each trend: social, political, economic, technological and legal.

Table 1: The 29 societal trends having an impact on mobility and logistics and their categories

\begin{tabular}{|c|c|c|}
\hline Categories & Trends & Type of trend \\
\hline \multirow[t]{2}{*}{$\begin{array}{l}3.1 \text { Economic } \\
\text { trends }\end{array}$} & $\begin{array}{l}\text { Share of the European economy in world GDP } \\
\text { declines }\end{array}$ & Economic \\
\hline & Restructuring working arrangements & Economic, Social \\
\hline \multirow[t]{8}{*}{3.2 Societal trends } & Increasing life expectancy of the population & Social \\
\hline & Migration trend generating long distance flows & Social \\
\hline & $\begin{array}{l}\text { Trend towards inclusion of vulnerable to exclusion } \\
\text { groups }\end{array}$ & Political \\
\hline & Less car usage by younger generations & Social \\
\hline & Move towards more active and healthy lifestyles & Social \\
\hline & Acceleration and flexibility of liquid modern society & Social \\
\hline & Personalisation of liquid modern society & Social \\
\hline & European integration facilitating flows & Political \\
\hline \multirow[t]{2}{*}{ 3.3 Urbanisation } & Rising and expanding urbanisation & Economic, Social \\
\hline & The emergence of Smart cities & Technological \\
\hline \multirow{4}{*}{$\begin{array}{l}\text { 3.4 Environmental } \\
\text { protection }\end{array}$} & Stricter regulations for environmental protection & Social, Political \\
\hline & $\begin{array}{l}\text { Limited resources require more resource efficiency } \\
\text { and circular economy in transport }\end{array}$ & Economic, Social \\
\hline & $\begin{array}{l}\text { Move away from fossil fuels towards energy } \\
\text { efficiency and renewable energies }\end{array}$ & $\begin{array}{l}\text { Political, } \\
\text { Economic, } \\
\text { Technological }\end{array}$ \\
\hline & Impact of climate change on tr & Environmental \\
\hline \multirow{4}{*}{$\begin{array}{l}\text { 3.5 Digital society } \\
\text { and the Internet of } \\
\text { things }\end{array}$} & Rise of the Internet of Things and big data & Technological \\
\hline & More automation & Technological \\
\hline & $\begin{array}{l}\text { Expectation of customers and digitisation of } \\
\text { mobility }\end{array}$ & Social \\
\hline & New uses of travel-time & Social \\
\hline \multirow[t]{3}{*}{$\begin{array}{l}\text { 3.6 Novel Busines } \\
\text { models in transport }\end{array}$} & $\begin{array}{l}\text { New models challenging the individual vehicle } \\
\text { ownership model }\end{array}$ & Economic, Social \\
\hline & New players and new business models & Economic \\
\hline & $\begin{array}{l}\text { Emerging co-development and co-creation of new } \\
\text { systems by users and economic actors }\end{array}$ & Economic \\
\hline \multirow{2}{*}{$\begin{array}{l}\text { 3.7 Safety in } \\
\text { transport }\end{array}$} & The persisting issue of transport safety & Social, Political \\
\hline & $\begin{array}{l}\text { The emerging safety issue in complex networks with } \\
\text { new vehicles }\end{array}$ & Social, Legal \\
\hline $\begin{array}{l}3.8 \text { Security in } \\
\text { transport }\end{array}$ & Growing concern over security threats & Social \\
\hline
\end{tabular}




\begin{tabular}{|l|l|l|}
\hline $\begin{array}{l}\text { 3.9 Legislative } \\
\text { framework }\end{array}$ & Diversifying approaches of governance & Political, Legal \\
\cline { 2 - 3 } & $\begin{array}{l}\text { Legislative models adapts to new transport solutions } \\
\text { and businesses }\end{array}$ & Legal \\
\cline { 2 - 3 } & $\begin{array}{l}\text { Trend toward harmonisation in legislative } \\
\text { frameworks }\end{array}$ & Legal \\
\hline
\end{tabular}

Considering that trends can be of several types, it can be observed that 16 trends are social, 8 trends are economic, 6 trends are political, 4 are technological, 4 are legal, and only one is environmental. If, as expected, more than half of the trends refer directly to social issues, the other aspects play a significant role in the description of trends.

The next section describes the trend categories in detail. ${ }^{2}$

\subsection{Economic trends}

Economic climate and economic conditions play a major role in shaping the demand for mobility. In the economic domain two trends have been identified. Firstly, it is foreseen that the adaptation of Europe's economy in the global context will have a relative decline of GDP (Bassanini and Reviglio 2011). European GDP and population should grow but much slower than the rest of the world on average. The direct consequence of global growth will be an increase in flows, particularly freight, but also the possibility of a re-industrialisation of Europe, which could lead to significantly modified freight flows ('ITF Transport Outlook 2017' 2017). At the individual level, economic growth usually converts into more mobility, as illustrated by the growth of tourism.

The second trend within this category refers to the restructuring of working arrangements. Telework and part-time work are the two major foreseeable tendencies already at work and that should grow in the future (Isusi and Corral 2004; Jagger et al. 2014). They have direct and indirect effects on mobility. Although there is a decreasing quantity of home-to-work flows, they could take longer due to the urban sprawl made easier by telework and less peak hour traffic, as there may be more trips for other purposes (Jackson and Victor 2011; Bernardino, Vieira, and Garcia 2013). A likely consequence of the last effect has been identified as a demand for more flexible tickets for public transport.

\subsection{Societal trends}

The second category of trend refers to societal dynamics that interact with mobility and freight demand. Most of these trends are mainly societal dynamics such as; "Increasing life expectancy of the population" or "Migration trend generating long distance flows", but some of them are also supported by "Move towards more active and healthy lifestyles" or driven by "Trend towards inclusion of vulnerable to exclusion groups" and "European integration facilitating flows".

2 For a detailed description of trends see (L’Hostis et al. 2016). 
"Increasing life expectancy of the population" is an essential dynamic of European societies (Eurostat 2015; World Health Organization and The World Bank 2011). The interaction with mobility and logistics are complex though: the population of car drivers is likely to grow, and less active mobility is expected from the "oldest old", but maybe more active mobility will come from those who will stay or move back to denser urban areas; a need for proximity in goods and service deliveries for the urban elders contrasts with specific and costly mobility demand in ageing rural areas (Anderton et al. 2015; Velaga, Beecroft, and Nelson 2012).

"Migration trend generating long distance flows" (European Commission 2011) introduces or develops specific patterns of mobility demand: the foreseen increasing migration in Europe will generate longer distance flows of persons and goods with the countries of origin of migrants ('Asylum Statistics - Statistics Explained' 2016; Vasileva 2009).

There is a consensus on the fact that policies support a "Trend towards inclusion of vulnerable to exclusion groups” (Martens 2012). This trend has a direct impact on transport policy in terms of accessibility for all. In addition to known vulnerable groups, the digitisation of mobility carries the risk of creating new exclusion, for instance among those who do not own a smartphone (Pauzié 2013; Velaga, Beecroft, and Nelson 2012).

Forming part of the explanation of the peak car phenomenon, the tendency of "Less car usage by younger generations" has been observed recently since the mid-2000 (Davis, Dutzik, and Baxandall 2012; Goodwin 2012; Newman, Kenworthy, and Glazebrook 2013; Metz 2013). Connecting to the social network, whatever the means, physically based or telecommunication based, seems to have replaced the car ownership dream observed in previous generations (Deloitte, Corwin, et al. 2015; McKinsey et al. 2012).

Another consequence of the societal awareness for environmental issues is the "Move towards more active and healthy lifestyles". This trend is fuelled by individual awareness and by policies aimed at influencing individual behaviour. Health is likely to become a major concern in the future with direct implications for the policies aimed at orientating mobility behaviour (Krzyzanowski, KunaDibbert, and Schneider 2005).

There is an emerging consensus among social scientists around the idea of liquid modernity introduced by Z. Bauman (Bauman 2000). In order to characterise the interactions of liquid modernity with mobility and logistics two trends have been established: "Acceleration and flexibility of liquid modern society" and "Personalisation of liquid modern society". The first trend refers to the ideas of acceleration and flexibility and provides an explanation to the increase of leisure time and its associated mobility patterns (Harvey 1990; Levine 1998; Rosa 2003). It also entails that transport users need less time for planning their trips, and have access to immediate and seamless information. The second trend of liquid modernity highlights the personalisation aspect. The individualisation process, illustrated among other indicators by the decreasing size of households (Euromonitor 2013; Capros et al. 2013), favours individual transport modes of 
cars but also bike and walking, and also favours models of the type "one-stopshop" for mobility services.

Essentially driven by policies and political choices "European integration facilitating flows" is still, despite the recent reverse movement by the United Kingdom, an ongoing process. Its impacts on mobility are straightforward through the increase in tourism and freight flows in Europe (Kester 2014).

\subsection{Urbanisation}

Urbanisation is the major trend of human settlement. Despite an already high level of urbanisation in Europe, it is foreseen that urbanisation is set to increase from $73 \%$ in 2014 to $84 \%$ in 2050 (United Nations 2014).

Cities and city-regions, which are densifying and spatially extending, are increasingly the dominant forms of settlement (Fujita, Krugman, and Venables 2001). These trends lead to more intense and longer urban flows, both for passengers and goods (Sena e Silva et al. 2013).

The emerging model of the smart city aims at articulating human and social development with information and communication technologies in cities (European Investment Bank Institute EIB 2013). Equipping cities with ICT infrastructure is being led by the introduction of new technologies of mobility (mainly electric vehicles, car sharing, car-pooling) and should lead to new social interactions and to new uses of city spaces, and hence should have significant impact on mobility behaviour and freight demand.

\subsection{Environmental protection}

In the domain of environmental protection, four trends can be identified. The first three are led or encouraged by policies, while the last one refers to the management of the consequences of climate change.

Rising awareness for environmental issues leads to the adoption of "Stricter regulations for environmental protection". Transport has a large impact on the environment, and is confronted with the strategic policy goals of decarbonisation (Pachauri and Meyer 2014; Anderton et al. 2015).

The economy is adapting in the context of increasingly limited resources available ("Limited resources require more resource efficiency and circular economy in transport"). A "sustainable consumption" culture emerges among citizens and firms tend to conform to social and environmental rules and approaches: corporate responsibility, circular economy, life cycle assessment (Petersen et al. 2009). All these elements will require the reconsideration of the organisation of logistics, as for instance in the case of local food consumption that need short supply chains (Blanke and Burdick 2005; Coley, Howard, and Winter 2009; Meisterling, Samaras, and Schweizer 2009; Kulak et al. 2015; Dablanc et al. 2016). 
In the domain of energy, policy goals support a movement to "Move away from fossil fuels towards energy efficiency and renewable energies" (European Commission 2011; Harrison 2013). The current dependence of transport on fossil fuels is expected to be replaced by more electricity and biofuels (Pachauri and Meyer 2014).

Finally, regarding environmental trends, the "Impact of climate change on transport” is direct and significant. Extreme weather events cause damages to transport systems of road, rail and aviation (Doll, Klug, and Enei 2014). Global warming could have one positive effect though, to open the North-West passage for freight between Europe and Asia (Anderton et al. 2015).

\subsection{Digital society and the Internet of things}

In this section on digital society, two types of trends are covered. Regarding the digital world, technology, as an enabler, exerts a real influence and drives individual and social uses. Two technological trends of "Internet of things and big data", and "automation" form the supply side. But at the same time, technology is sometimes used for a slightly different purpose than what was foreseen by the designers. In this sense, individuals and social groups can be seen as actors of digital society, and able to fuel trends that are not driven by technology. This is the demand side of digital society.

The technological trends of "Rise of the Internet of Things and big data" is impacting many aspects of the production of goods and services, and particularly in the transport domains. Vehicles, transport infrastructures, ICT devices, parcels will all be able to communicate in real-time. Dealing with the masses of data produced require new methods, the so called big data approaches, but promise to improve many transport issues like transport operations planning, traffic management, or safety (Löffler and Tschiesner 2016; Jeske, Grüner, and Weiss 2013; Zakir, Seymour, and Berg 2015).

The trend of "More automation" is driven by the development of artificial intelligence, sensors and information and communication technologies (Frisoni et al. 2016). This technological development has ambitious road safety promises, but also raises difficulties expressed in another trend ("The emerging safety issue in complex networks with new vehicles”). Automation is also developing in the air and rail transport domains (Verstraeten and Kirwan 2014).

Regarding the demand side of the digital society, the first trend refers to the "Expectation of customers and digitisation of mobility". Travellers in the digital world expect to be able to connect their mobile devices, and expect to receive accurate and real-time information about their trips (Pauzié 2013). All these expectations are challenging for transport providers (Deloitte, Goodall, et al. 2015). Quite ambivalently, travellers also want more data privacy (Pauzié 2013)

Mostly driven by the development of the digital society, "New uses of traveltime" can be observed (Jain and Lyons 2008; Lyons et al. 2013). Usually seen as a burden, travel time can become a positive moment for users. This trend is able to 
influence the transport mode choice in favour of public transport (Russell 2012), until automation is introduced.

\subsection{Novel Business models in transport}

The transport sector witnesses the emergence of new players and new business models interacting with - if not fuelled by - new behaviour. New business models are closely related to the previously mentioned trend of "Rise of the Internet of Things and big data". The main issue is the currently dominating individual vehicle ownership model, described in the first trend "New models challenging the individual vehicle ownership model" (Shaheen, Mallery, and Kingsley 2012; Hardesty 2014; Cirstea 2015). The second trend covers the other cases where new players and new business models emerge, in batteries, in data, in freight "New players and new business models" (Forbes 2015; Leminen et al. 2015; Rantasila et al. 2014; Casey and Valovirta 2016). The last trend highlights the emergence of the co-development model and its implications for mobility: "Emerging co-development and co-creation of new systems by users and economic actors”(Chang and Yen 2012; Finnish Prime Minister's Office 2015; Kostiainen, Aapaoja, and Hautala 2016)

\subsection{Safety in transport}

Despite significant improvement of the levels of safety, especially in the road transport domain, and encouraging perspectives linked to automation, transport safety will most probably remain a pressing issue in the future ('European Commission Press Release - 2015 Road Safety Statistics: What Is behind the Figures?' 2015).

Considering the long-term promise of the decrease in road casualty through the introduction of automated cars, a new safety issue emerges with the coexistence of automatic and non-automatic vehicles, creating complex networks and environments (Lazakis 2014). Safety will become a far more complex issue than today with new insurance and liability issues (Smith and Svensson 2015).

\subsection{Security in transport}

Terrorism is a growing concern in our societies and for governments (Zellner 2014). Attacks often target transportation infrastructure, and hence the interaction between this trend and mobility and freight is straightforward (Jenkins 2007). More security is expected which raises the security and accessibility tension: the provision of more security in transport by introducing controls and barriers reduces accessibility. 


\subsection{Legislative framework}

The legislative dimension converts societal demand, through the production of laws and rules by public authorities and jurisprudence. This legislative dimension is an expression of the broader policy process and institutional environment that directly affects the transport sector. Nevertheless, beyond the mere role of translation of societal demand, the legislative dimension can be considered as a dynamic on its own, and hence can be considered as a societal trend in the broad sense. Three legislative trends exert influence in the domains of mobility and logistics.

We observe in the legislative domain a trend of "Diversifying approaches of governance“ (European Environment Agency 2015). More actors are invited to contribute to the governance of transport and mobility. In particular, with the association of citizens in decision processes, more transparency is required in governance models (Albrechts 2010). The innovation at play in the domain of legislation and governance, leads to a diversification of governance models.

Secondly, with the trend "Legislative models adapting to new transport solutions and businesses" an interaction occurs between new business models and the legislative framework. The legislative framework has to adapt to new solutions (Azevedo and Maciejewski 2015), but newcomers must also make sure their business can sustain in a given and changing legislative framework.

The "Trend toward harmonisation in legislative frameworks" of the legislative framework in Europe has direct implications for transport, in the aims of interoperability of transport systems ('Road Transport: Harmonisation of Legislation | EU Fact Sheets | European Parliament' 2016). This trend refers also to the fact that legislative adaptations to new models and solutions in a given European country will inspire other countries' reactions.

\section{$4 \quad$ Interrelations between trends}

In this section we present the main interrelations between these trends. Even though this work mostly identified and isolate individual factors interacting with mobility and logistics in an unequivocal sense, the intrinsically interdependent nature of our material cannot be ignored.

The main interactions between trends form three groups. A small group links societal dynamics to policies aimed at correcting or accompanying them. A large group includes all the links between societal trends and digital technologies. Finally, a few remaining interrelations are identified beyond these two categories. 
The first group of interrelations links policies, expressing the will of policy makers, and societal trends as actual transformations in the social field. Several emerging trends in transport demand are pushed by policies, but can also be seen as reflecting societal demand. This is the case in the environmental protection domain where a sustainable consumption culture interacts with extensive sets of policies dedicated to environment protection. Hence, the present analysis mixes societal trends, like ageing, and political responses to identified issues like policies aiming at inclusion of vulnerable groups.

The second group of interrelations links society and digital technologies.

The liquid modern society described by Bauman (Bauman 2000), is intimately shaped by digital technologies of information and communication. There is hence clearly a strong link between the two trends of liquid modernity and the four trends of the digital society. The current and future digital society would not exist without the technology developments in communication and information, but, on the other hand, the use by individuals and social groups is not always envisaged by the creators of services, yet contribute significantly to shaping the digital society. In this sense, digital society is shaped by technology and by societal factors. As is well known in the domain of transport infrastructure, a new supply generates a demand that was not expressed before: this is the so called induced demand. Digital society is rooted in the societal trends of liquid modernity, and also influences the transport demand. The expectation of the customer having a specific dynamic in the digital world. And the digital society does not limit to transport user requirement, but has deep interactions with mobility in general, including avoiding mobility.

The observed reduction in car use by younger generations has been seen by several analysts as linked to a change in values. The possession of a car tends to be replaced by the idea of connecting to the social network; this points to the use of ICT and hence to several trends identified in the digital society section.

A trend towards the inclusion of vulnerable groups can be identified. But in the emerging digital society new forms of exclusion arise; these forms are particularly of concern in the transport and mobility sectors. Here a clear issue lies at the intersection of public policies aiming at inclusion and the development of new transport services making use of ICT.

We have identified a trend of new uses of travel time, mainly by means of ICT that currently favours public transport. But, in the future car automation is likely to erase this comparative advantage. A complex interaction of trends exists here, with evolving developments over time.

Beyond the two categories of interrelations, three other linkages can be identified.

Complex interactions link automation and transport safety. Automation comes with the promise of significant improvement of the levels of safety in transport, but it also introduces new kinds of safety problems; an illustration is the selfdriven Tesla car casualty accident in 2016 and the many similar events since then. This represents a new type of accident raising significant liability and insurance issues most likely to impact the legislative and regulatory frameworks. 
The responses to the security threat perception, as noted, carries the risk of introducing more controls that may be detrimental to the ease of access and use of collective transport systems. The trend of a security versus accessibility tension is clearly contrary to the fluidity, acceleration and flexibility features of the liquid modern society.

Liquid modernity is both a consequence, or a symptom, and a source for the observed restructuring working arrangements. Indeed, the observation of acceleration is paradoxically based on the growing mobility for non-work purposes, and hence directly related to the idea of growing part-time work described in the restructuring arrangement trend. This forms an example of the links between economy and society.

This review of linkages was necessary to reveal the complexity of the system of trends. This review also contributes to validating the list of trends, by distinguishing many factors for the understanding of the present and future dynamics between society and transport.

\section{$5 \quad$ Conclusion}

This paper focuses on the identification and description of societal trends shaping the demand of mobility and logistics. The work has led to the identification of a list of 29 societal trends covering societal trends, political, economic, technological and legal trends. The result of this investigation forms a broad and comprehensive set of factors that influence, and will influence future, mobility and logistics. This approach has been organised so that, even if trends are linked one to another, as can be seen in the last section, no duplication can be found in the set of trends. This set borrows characteristics of a system in the sense that individual sub-parts, once assembled, form a coherent set.

This work has been strongly inspired by the ideas of the liquid modernity developed by Bauman. Liquid modernity highlights key societal trends of individualism, of the fluidity of society, of the feeling of acceleration of the pace of life, of the growing importance of social networks, and of the role of information and communication technologies. This broad and complete view on societal trends has proved to be very supportive of the present analysis. It allows to describe linkages between social and economic trends, and between society and technology, especially information and communication technology. Basing the analysis on liquid modernity provides coherence and exhaustiveness in covering the topic.

The added value of this contribution is its systematic approach and that evidence is provided for each identified trend. The proposal forms a broad and comprehensive view of societal trends that play, and will play, a role in shaping the demand for mobility and logistics in Europe at the horizon 2030. The trends identified in this paper form the bases of the scenario building in the Mobility4EU 
project which is the subject of the paper "Building scenarios for the future of transport in Europe: The Mobility4EU approach” in Chapter X.

\section{Acknowledgements}

The authors thank, Corinne Blanquart, Freek Bos, Annette Brückner, Thierry Coosemans, Laetitia Dablanc, Erzsébet Földesi, Alessia Golfetti, Stefania Grosso, George Holley-Moore, Juho Kostiainen, Jochen Langheim, Gereon Meyer, Linda Napoletano, Cristina Pou, Annette Randhahn, Joachim Skoogberg, Yves Stans, Anu Tuominen, Marcia Urban, Susana Val, Ineke van der Werf for their inputs in this work.

The authors thank Amna Diaz from ILC for language check.

The authors wish to thank the European Commission for the funding of the MOBILITY4EU project in the framework of the Horizon2020 program (EC Contract No. 690732).

\section{$7 \quad$ References}

Albrechts, Louis. 2010. 'More of the Same Is Not Enough! How Could Strategic Spatial Planning Be Instrumental in Dealing with the Challenges Ahead?' Environment and Planning B: Planning and Design 37 (6): 1115-1127.

Anderton, Karen, Ralf Brand, Merethe Dotterud Leiren, Henrik Gudmundsson, Max Reichenbach, and Jens Schippl. 2015. 'TRANSFORuM Urban Mobility Roadmap'. European Comission. http://www.transforumproject.eu/fileadmin/user_upload/08_resources/0801_library/TRANSFORuM_Roadmap_Urban.pdf.

'Asylum Statistics - Statistics Explained’. 2016. Accessed 29 July 2016. http://ec.europa.eu/eurostat/statistics-explained/index.php/Asylum_statistics.

Azevedo, Filpa, and Mariusz Maciejewski. 2015. 'Social, Economic and Legal Consequences of Uber and Similar Transportation Network Companies (TNCs) Think Tank'. Briefing. European Parliament. http://www.europarl.europa.eu/thinktank/en/document.html? reference=IPOL_BRI(2015)563398.

Bassanini, Franco, and Edoardo Reviglio. 2011. 'Financial Stability, Fiscal Consolidation and Long-Term Investment after the Crisis'. OECD Journal: Financial Market Trends 2011 (1): 31-75.

Bauman, Zygmunt. 2000. Liquid Modernity. Vol. 9. Polity Press Cambridge. http://neilsquire.pbworks.com/w/file/fetch/35116162/Bauman-Liquid\%EE \%80\%80Modernity\%EE\%80\%81.pdf. 
Bernardino, João, João Vieira, and Hugo Garcia. 2013. 'FUTRE Deliverable 3.1: Factors of Evolution of Demand and Pathways'. European Comission. http://www.futre.eu/Publications/Deliverables.aspx.

Blanke, Michael, and Bernhard Burdick. 2005. 'Food (Miles) for Thought-Energy Balance for Locally-Grown versus Imported Apple Fruit (3 Pp)'. Environmental Science and Pollution Research 12 (3): 125-127.

Boschmann, E. Eric, and Mei-Po Kwan. 2008. 'Toward Socially Sustainable Urban Transportation: Progress and Potentials’. International Journal of Sustainable Transportation 2 (3): 138-57. https://doi.org/10.1080/15568310701517265.

Brög, Werner, Franz Barta, and Erhard Erl. 2005. 'Societal Megatrends: Like It or Not, the Framework Is Set'. In 56th UITP World Congress. http://socialdata.de/info/Societal\%20Megatrends\%20-\%20UITP\%20Plenary \%20Presentation.pdf.

Capros, P., A. De Vita, N. Tasios, D. Papadopoulos, P. Siskos, E. Apostolaki, M. Zampara, et al. 2013. EU Energy, Transport and GHG Emissions: Trends to 2050, Reference Scenario 2013. https://trid.trb.org/view.aspx?id=1285618.

Casey, Thomas, and Ville Valovirta. 2016. 'Towards an Open Ecosystem Model for Smart Mobility Services’. Espoo: VTT. http://www.vtt.fi/inf/pdf/technology/2016/T255.pdf.

Chang, Yuan-Chieh, and HsiuJu Rebecca Yen. 2012. 'Introduction to the Special Cluster on Managing Technology-service Fusion Innovation'. Technovation 32 (7): 415-418.

Cirstea, Alice. 2015. 'The Implications of Mobile Commerce Applications: The Case Study of Uber in Romania'. International Journal of Scientific Knowledge 6 (2): $1-5$.

Clegg, Stewart, and Carmen Baumeler. 2010. 'Essai: From Iron Cages to Liquid Modernity in Organization Analysis’. Organization Studies 31 (12): 1713-33. https://doi.org/10.1177/0170840610387240.

Coley, David, Mark Howard, and Michael Winter. 2009. 'Local Food, Food Miles and Carbon Emissions: A Comparison of Farm Shop and Mass Distribution Approaches'. Food Policy 34 (2): 150-155.

Dablanc, Laetitia, Corinne Blanquart, François Combes, Adeline Heitz, Jens klausberg, Martin Koning, Zeting Liu, and Sasha Seidel. 2016. 'CITYLAB Observatory of Strategic Developments Impacting Urban Logistics (2016 Version)'. Deliverable 2-1 CITYLAB European Project. http://www.citylab-project.eu/deliverables/D2_1.pdf: European Commission H2020 Programme. http://www.citylabproject.eu/deliverables/D2_1.pdf.

Dablanc, Laetitia, Eleonora Morganti, Niklas Arvidsson, Johan Woxenius, Michael Browne, and Neila Saidi. 2017. 'The Rise of On-Demand "Instant Deliveries” in European Cities'. In Supply Chain Forum: An International Journal, 115. Taylor \& Francis.

Davis, Benjamin, Tony Dutzik, and Phineas Baxandall. 2012. 'Transportation and the New Generation: Why Young People Are Driving Less and What It Means for Transportation Policy'. http://trid.trb.org/view.aspx?id=1141470. 
Deloitte, Scott Corwin, Joe Vitale, Eamonn Kelly, and Elizabeth Cathles. 2015. 'The Future of Mobility, How Transportation Technology and Social Trends Are Creating a New Business Ecosystem'. http://www2.deloitte.com/ru/en/pages/manufacturing/articles/future-of-mobility.html.

Deloitte, Warwick Goodall, Tiffany Fishman, Simon Dixon, and Costi Perricos. 2015. 'Transport in the Digital Age, Disruptive Trends for Smart Mobility'. Deloitte.

Doll, Claus, Stefan Klug, and Riccardo Enei. 2014. 'Large and Small Numbers: Options for Quantifying the Costs of Extremes on Transport Now and in 40 Years'. Natural Hazards 72 (1): 211-39.

Euromonitor. 2013. 'Downsizing Globally: The Impact of Changing Household Structure on Global Consumer Markets’. http://www.euromonitor.com/downsizing-globally-the-impact-of-changing-household-structure-on-global-consumermarkets/report.

European Commission. 2011. 'Impact Assessment Accompanying Document to the White Paper: Roadmap to a Single European Transport Area - Towards a Competitive and Resource Efficient Transport System'. http://eurlex.europa.eu/legal-content/EN/ALL/?uri=CELEX:52011DC0144.

'European Commission Press Release - 2015 Road Safety Statistics: What Is behind the Figures?' 2016. Accessed 27 June 2016. http://europa.eu/rapid/pressrelease_MEMO-16-864_en.htm.

European Environment Agency. 2015. 'Assessment of Global Megatrends Extended Background Analysis — European Environment Agency’. Publication 11/2015. EEA Technical Report. Luxembourg: European Environment Agency. http://www.eea.europa.eu/publications/global-megatrends-assessment-extendedbackground-analysis.

European Investment Bank Institute EIB. 2013. 'Smart Cities. Concept and Challenges, Assessing Smart City Initiatives for the Mediterranean Region (ASCIMER)’. 2013. http://www.eiburs-ascimer.transyt-projects.com/.

Eurostat. 2015. 'Key Figures on Europe, 2015 Edition’. Statistical Books. Eurostat.

Finnish Prime Minister's Office. 2015. 'Finland, a Land of Solutions Strategic Programme of Prime Minister Juha Sipilä’s Government’. Prime Minister’s Office Finland.

Forbes. 2015. 'Tesla's Business Model Highlights What The Shift To Electric Means For The Auto Industry’. 2015. http://www.forbes.com/sites/greatspeculations/2015/09/01/teslas-business-model-highlights-what-the-shift-to-electricmeans-for-the-auto-industry/\#4b8daf945029.

Frändberg, Lotta, and Bertil Vilhelmson. 2011. 'More or Less Travel: Personal Mobility Trends in the Swedish Population Focusing Gender and Cohort'. Journal of Transport Geography, Special section on Alternative Travel futures, 19 (6): 1235-44. https://doi.org/10.1016/j.jtrangeo.2011.06.004.

Frisoni, Roberta, Andrea Dall’Oglio, Craig Nelson, James Long, Christoph Vollath, Davide Ranghetti, Sarah McMinimy, and Steer Davies Gleave. 2016. 'Research for TRAN Committee - Self-Piloted Cars: The Future of Road Trans- 
port?' European Parliament, Directorate-General for internal policies, policy department B: Structural and Cohesion Policies, Transport and Tourism.

Fujita, Masahisa, Paul R. Krugman, and Anthony Venables. 2001. The Spatial Economy: Cities, Regions, and International Trade. MIT press. https://books.google.fr/books?hl=fr\&lr=\&id=07Mzawou-8EC\&oi=fnd\&pg=PR11\&dq=+europe+cities+regions+power\&ots=LI6X4g_N9J\&sig=Ip-T9_iv4kcK-

QecmWrV03AqRbvU.

Goodwin, Phil. 2012. 'Three Views on Peak Car'. World Transport, Policy and Practice 17. http://eprints.uwe.ac.uk/16119/21/wtpp17.4.pdf\#page=9.

Granovetter, Mark. 1983. 'The Strength of Weak Ties: A Network Theory Revisited'. Sociological Theory 1: 201-33.

Hardesty, Larry. 2014. 'Ride-Sharing Could Cut Cabs' Road Time by 30 Percent'. MIT News, 1 September 2014. http://news.mit.edu/2014/rideshare-data-cuttaxi-time-0901.

Harrison, $\quad$ Pete. 2013. 'Fuelling Europe's Future'. http://www.camecon.com/EnergyEnvironment/EnergyEnvironmentEurope/FuellingEuropesFuture.aspx.

Harvey, David. 1990. 'The Condition of Postmodernity: An Enquiry into the Conditions of Cultural Change'. http://www.citeulike.org/group/14819/article/9699561.

Isusi, Inigo, and Antonio Corral. 2004. 'Part-Time Work in Europe'. EurWORK. http://www.eurofound.europa.eu/observatories/eurwork/comparative-information/part-time-work-in-europe.

'ITF Transport Outlook 2017'. 2017. International Transport Forum/OECD. http://www.oecd.org/about/publishing/itf-transport-outlook-2017-

9789282108000-en.htm.

Jackson, Tim, and Peter Victor. 2011. 'Productivity and Work in the "Green Economy”: Some Theoretical Reflections and Empirical Tests’. Environmental Innovation and Societal Transitions 1 (1): 101-108.

Jagger, Carol, Pia Wohland, Tony Fouweather, and Tom Kirkwood. 2014. 'Raising the Retirement Age: Implications for UK and Europe'.

Jain, Juliet, and Glenn Lyons. 2008. 'The Gift of Travel Time'. Journal of Transport Geography $16 \quad$ 81-89. https://doi.org/10.1016/j.jtrangeo.2007.05.001.

Jenkins, Brian Michael. 2007. 'The Terrorist Threat to Surface Transportation'. National Transportation Security Center. Mineta Transportation Institute. http://scotsem.transportation.org/Documents/Jenkins--TheTerroristThreattoSurfaceTransportation.pdf.

Jeske, M., M. Grüner, and F. Weiss. 2013. 'Big Data in Logistics: A DHL Perspective on How to Move beyond the Hype'. DHL Customer Solutions \& Innovation 12.

Kaufmann, Vincent. 2002. 'Re-Thinking Mobility’. http://hal.archives-ouvertes.fr/halshs-00439011/.

Kellerman, Aharon. 2012. Daily Spatial Mobilities: Physical and Virtual. Ashgate Publishing Limited. 
Kester, John GC. 2014. '2013 International Tourism Results and Prospects for 2014'. UNWTO

News. http://cf.cdn.unwto.org/sites/all/files/pdf/unwto_fitur_2014_hq_jk_2pp.pdf.

Kostiainen, J, A Aapaoja, and R Hautala. 2016. 'Public Transport ITS Test Environment for a Smart City’. presented at the 11th ITS European Congress, Glasgow, June. http://glasgow2016.itsineurope.com/.

Krzyzanowski, Michal, Birgit Kuna-Dibbert, and Jürgen Schneider. 2005. Health Effects of Transport-Related Air Pollution. WHO Regional Office Europe. https://books.google.fr/books?

$\mathrm{hl}=\mathrm{fr} \& \mathrm{lr}=\& \mathrm{id}=\mathrm{b} 2 \mathrm{G} 3 \mathrm{k} 51 \mathrm{rd0oC} \& \mathrm{oi}=\mathrm{fnd} \& \mathrm{pg}=\mathrm{PR} 1 \& \mathrm{dq}=$ Health+effects+ of + trans port-related+air+pollution\&ots=065x2DGs9z\&sig=5IKuTQngcA2LTFbzrGmfwhUs4ZY.

Kulak, Michal, Thomas Nemecek, Emmanuel Frossard, Véronique Chable, and Gérard Gaillard. 2015. 'Life Cycle Assessment of Bread from Several Alternative Food Networks in Europe'. Journal of Cleaner Production 90: 104-113.

Lazakis, Iraklis. 2014. 'EXCROSS Final Report on Synergies and Opportunities’. European Commission. http://www.excross.eu/deliverables.htm.

Leminen, Seppo, Mervi Rajahonka, Mika Westerlund, and Riikka Siuruainen. 2015. 'Ecosystem Business Models for the Internet of Things'. In Internet of Things Finland, Digile, 10-13. https://www.google.fr/url? $\mathrm{sa}=\mathrm{t} \& \mathrm{rct}=\mathrm{j} \& \mathrm{q}=$ \&esrc$=\mathrm{s} \&$ source $=$ web\&cd $=1$ \&ved=0ahUKEwjt9bSQpazMAhULXhoKHaS-BHwQFggdMAA\&url=http\%3A\%2F\%2Fwww.internetofthings.fi\%2Fextras\%2FIoTMagazine2015.pdf\&usg=AFQjCNGXos4lcQk1GCkVVtpZFkm6Q8bMgw\&sig2=Gmp3uRCtXifJaxsUtE6CdQ.

Lemmerer, Helmut, and Paul Pfaffenbichler. 2012. 'ORIGAMI Deliverable 3.1 Current Travel Behaviour, Future Trends and Their Likely Impact’. Edinburgh: European Commission. www.origami-project.eu.

Levine, Robert V. 1998. A Geography Of Time: The Temporal Misadventures of a Social Psychologist. Revised ed. edition. Basic Books.

L'Hostis, Alain, Beate Müller, Gereon Meyer, Annette Brückner, Erzsebet Foldesi, Laetitia Dablanc, Corinne Blanquart, et al. 2016. 'MOBILITY4EU - D2.1 - Societal Needs and Requirements for Future Transportation and Mobility as Well as Opportunities and Challenges of Current Solutions'. Research Report. IFSTTAR - Institut Français des Sciences et Technologies des Transports, de l'Aménagement et des Réseaux. https://hal.archives-ouvertes.fr/hal-01486783.

Löffler, Markus, and reas Tschiesner. 2016. 'The Internet of Things and the Future of Manufacturing | McKinsey \& Company’. Accessed 8 July 2016. http://www.mckinsey.com/business-functions/business-technology/ourinsights/the-internet-of-things-and-the-future-of-manufacturing.

Lyons, Glenn, Juliet Jain, Yusak Susilo, and Stephen Atkins. 2013. 'Comparing Rail Passengers' Travel Time Use in Great Britain between 2004 and 2010'. Mobilities 8 (4): 560-579.

Martens, Karel. 2012. 'Justice in Transport as Justice in Accessibility: Apply ing Walzer's 'Spheres of Justice’to the Transport Sector'. Transportation 39 (6): 1035-1053. 
McKinsey, Andreas Cornet, Detlev Moh, Florian Weig, Benno Zerlin, and Arnt-Philipp Hein. 2012. 'Mobility of the Future, Opportunities for Automotive OEMs'.

Meisterling, Kyle, Constantine Samaras, and Vanessa Schweizer. 2009. 'Decisions to Reduce Greenhouse Gases from Agriculture and Product Transport: LCA Case Study of Organic and Conventional Wheat'. Journal of Cleaner Production 17 (2): 222-230.

Metz, David. 2013. 'Peak Car and beyond: The Fourth Era of Travel'. Transport Reviews 33 (3): 255-270.

Newman, Peter, Jeffrey Kenworthy, and Garry Glazebrook. 2013. 'Peak Car Use and the Rise of Global Rail: Why This Is Happening and What It Means for Large and Small Cities'. Journal of Transportation Technologies 03 (04): 272-87. https://doi.org/10.4236/jtts.2013.34029.

Pachauri, R. K., and L. A. Meyer. 2014. 'Fifth Assessment Report - Synthesis Report Contribution of Working Groups I, II and III to the Fifth Assessment Report of the Intergovernmental Panel on Climate Change'. https://www.ipcc.ch/report/ar5/syr/.

Pauzié, Annie. 2013. 'DECOMOBIL Deliverable 3.4 Nomadic Transport Services for Multimodal Mobility: Issues and Perspectives'. European Commission. http://decomobil.humanist-vce.eu/Downloads.html.

Petersen, Morten Steen, Carlo Sessa, Riccardo Enei, Andreu Ulied, Efrain Larrea, Oriol Obisco, P. Timms, and C. Hansen. 2009. 'TRANSvisions Final Report on Transport Scenarios with a 20 and 40 Year Horizon'. European Commission. http://81.47.175.201/flagship/attachments/2009_02_transvisions_report.pdf.

Rantasila, K, H Mantsinen, T Casey, R Hautala, and M Lankinen. 2014. 'Development of ITS Multi-Service from Idea to Deployment'. presented at the 10th ITS European Congress, Helsinki, June 16.

'Road Transport: Harmonisation of Legislation | EU Fact Sheets | European Parliament’. 2016. Accessed 27 June 2016. http://www.europarl.europa.eu/atyourservice/en/displayFtu.html?ftuId=FTU_5.6.4.html.

Rosa, Hartmut. 2003. 'Social Acceleration: Ethical and Political Consequences of a Desynchronized High-Speed Society’. Constellations 10 (1): 3-33.

Rudinger, Georg, Kieran Donaghy, and Stefan Poppelreuter. 2004. 'Societal Trends, Mobility Behaviour and Sustainable Transport in Europe and North America: The European Union Network STel LA'. European Journal of Ageing 1 (1): 95-101.

Russell, Marie Louise. 2012. 'Travel Time Use on Public Transport: What Passengers Do and How It Affects Their Wellbeing'. Thesis, University of Otago. http://otago.ourarchive.ac.nz/handle/10523/2367.

Sena e Silva, Miguel, Mónica Oliveira, Nuno Soares Ribeiro, Massimo Moraglio, Johanna Ludvigsen, Andreas Christ, Tiina- Maria Seppänen, et al. 2013. 'RACE2050 D5.1 - Current Transport Demand and Global Transport Outlook'. European Commission. http://www.race2050.org/index.php?id=4\#news.

Sessa, Carlo, and Riccardo Enei. 2009. 'EUTransportGHG Report EU Transport Demand: Trends and Drivers’. European Commission. http://www.eutrans- 
portghg2050.eu/cms/assets/EU-Transport-GHG-2050-Task3-Paper-EU-TransportTrends-and-Drivers-22-12-09-FINAL.pdf.

Shaheen, Susan A., Mark A. Mallery, and Karla J. Kingsley. 2012. 'Personal Vehicle Sharing Services in North America'. Flexible Transport Services 3 (August): 71-81. https://doi.org/10.1016/j.rtbm.2012.04.005.

Smith, Bryant Walker, and Joakim Svensson. 2015. 'Automated and Autonomous Driving: Regulation under Uncertainty’. https://trid.trb.org/view.aspx? id=1358502.

United Nations. 2014. World Urbanization Prospects: The 2014 Revision. UN.

Urry, John. 2007. Mobilities. Polity.

Vasileva, Katya. 2009. 'Citizens of European Countries Account for the Majority of the Foreign Population in EU-27 in 2008 - Issue Number 94/2009 - Product - Eurostat'. Eurostat. http://ec.europa.eu/eurostat/en/web/products-statistics-in-focus/-/KS-SF-09-094.

Velaga, Nagendra, Mark Beecroft, and John Nelson. 2012. 'Transport Poverty Meets the Digital Divide: Accessibility and Connectivity in Rural Communities'. Journal of Transport Geography 21: 102-12.

Verstraeten, Joram, and Barry Kirwan. 2014. 'OPTICS 2nd Expert Workshop: From Hazard Management to Operational Resilience'. European Commission.

Wilson, Steven. 2011. 'Transport Outlook 2011: Meeting the Needs of 9 Billion People'. Text. http://www.itf-oecd.org/transport-outlook-2011-meetingneeds-9-billion-people.

World Health Organization, and The World Bank. 2011. 'World Report on Disability 2011'. http://apps.who.int/iris/handle/10665/44575.

Zakir, Jasmine, Tom Seymour, and Kristi Berg. 2015. 'Big Data Analytics'. Issues in Information Systems 16 (2). http://www.iacis.org/iis/2015/2_iis_2015_8190.pdf.

Zellner, Wolfgang. 2014. Threat Perceptions in the OSCE Area. Institut für Friedensforschung und Sicherheitspolitik an der Universität Hamburg. https://ifsh.de/file-CORE/documents/core_news/CORE_News_Spring_2014.pdf.

\section{$8 \quad$ Full Authors' Information}

Eleni Chalkia

Center for Research and Technology Hellas (CERTH)

$6^{\text {th }} \mathrm{km}$ Charilaou-Thermi Rd

P.O. Box 60361

GR 57001 Thermi

Thessaloniki 
Greece

E-mail: hchalkia@certh.gr

Maria Teresa de la Cruz

Zaragoza Logistics Center

C/ Bari 55, Edificio Náyade 5 (PLAZA)

50197 Zaragoza

Spain

E-mail: mdelacruz@zlc.edu.es

Imre Keseru

Vrije Universiteit Brussel, Mobility, Logistics and Automotive Technology Research Centre (MOBI), Department Business Technology and Operations (BUTO)

Pleinlaan 2

BE-1050 Brussel

Belgium

E-mail: Imre.Keseru@vub.be

Alain L'Hostis

Université Paris-Est, LVMT (UMR_T 9403), Ecole des Ponts ParisTech, IFST-

TAR, UPEMLV

14-20 Boulevard Newton

Cité Descartes, Champs sur Marne

F-77447 Marne la Vallée Cedex 2

France

E-mail: alain.lhostis@ifsttar.fr

Beate Müller

VDI/VDE Innovation und Technik GmbH

Steinplatz 1

10623 Berlin

Germany

E-mail: Beate.Mueller@vdivde-it.de

\section{$9 \quad$ Keywords}

Mobility, Logistics, societal trends, liquid modernity 